\title{
COVID-19 Information Seeking and Utilization Among Women in Warri Metropolis, Delta State, Nigeria
}

Esharenana E. Adomi, Federal University of Petroleum Resources Library, Effurun, Delta State, Nigeria

Gloria O. Oyovwe-Tinuoye, Federal University of Petroleum Resources Library, Effurun, Delta State, Nigeria

\begin{abstract}
The study is intended to explore COVID-19 information seeking and utilization among women in Warri Metropolis, Delta State, Nigeria. Descriptive survey research design was adopted using a selfconstructed questionnaire to collect data. Data were analyzed using simple percentages. Findings revealed that a majority of the women need information on COVID-19 preventive measures, followed by causes of the pandemic. Internet is the source of COVID-19 information used by the highest number of respondents, followed by television and social media. A majority of them consider the authority of the source of the information on coronavirus followed by usefulness of the information. A majority access COVID-19 information to enable them identify symptoms of the disease followed by protection against COVID-19 infection while concern for reliability of much of the available information on the pandemic was a major barrier to their utilization of COVID-19 information. It is recommended that effort should be made by government to get mobile network operators to reduce network tariff.
\end{abstract}

\section{KEYWORDS}

COVID-19, Information Seeking and Use, Nigeria, Warri Metropolis, Women

\section{INTRODUCTION}

COVID-19 is a benign to acute respiratory illness which is caused by a coronavirus (Severe acute respiratory syndrome coronavirus 2 of the genus Betacoronavirus), chiefly transmitted by contact with infectious material (such as respiratory droplets) or with objects or surfaces which are contaminated by the causative virus, and is particularly characterized by fever, cough, and shortness of breath and can progress to pneumonia and respiratory failure (Merriam-Webster, Incorporated, 2020). The outbreak of COVID-19 pandemic has become worrisome in the world at large. COVID-19 first emerged and was diagnosed in Wuhan, Huebi Chinain November, 2019 and has been linked to the Huanan Seafood Market (South China) and the infection has spread to several countries around the world (Wang, Horby, Hayden \& Goa, 2020). Due to the widespread of COVID-19 in many countries around the world, the World Health Organisation (WHO), through its Director General (Dr Tedros Adhanom Ghebreyesus) at a media briefing on COVID-19 on 11th March, 2020, officially declared the COVID-19 outbreak a pandemic (World Health Organisation, 2020a). Ebhraim, Saif, Buheji, AlBasri, Al-Husaini, and Jahrami (2020) asserted that efforts have been directed by World Health 
Organisation towards ensuring appropriate levels of preparedness and response to combat the disease effectively and efficiently to manage the ramifications associated with the outbreak.

There has been profound impact of COVID-19 on women and girls in Africa as they are disproportionately affected by lockdowns which have resulted in reduced access to health and other services, economic hardship, increased gender-based violence among others(WHO, 2020b).

Information seeking, according to Igwe (2012), is an individual way or manner of gathering and sourcing information for personal use, knowledge updating and development. The society is trying to keep safe and stay healthy to ensure that the pandemic does not claim more lives by ensuring they get the necessary information about the pandemic and utilize it well. According to Warner and Procaccino (2004), women tend to be the primary seeker of information for their children and other family members as well as for themselves. Women are the caretaker of the families and it is of necessity that they are equipped with the relevant information on COVID-19 in order to protect themselves, their families and others from the pandemic and be able to the handle situations in case one or more of its members have contacted it or suspected of being infected with them.

Delta State is one of the thirty six states of Nigeria. It is located in the southern part of the country. Due to the strategic location of Delta State, there is regular influxes of people into the state on a daily basis, and due to the continuous spread of the disease, the Delta State House of Assembly called on the State Government to intensify the sensitisation of of the populace on the effects of this deadly disease, that proper sensitization was needed to put some certain measures in place to contain the spread; that the people needed to know and be aware of how to take precautionary measures against the disease (Vanguard Media Limited, 2020). The State Government embarked on measure to control and combat the spread of the pandemic, such as creating awareness on the disease and its prevention via the print, electronic and social media, - wearing of noise mask, ensuring that buckets of water, liquid soaps, hand sanitizers are placed at the entry of each organisation, maintaining social distance etc. Accordingly, Oliver, Lepri, Sterly, Renavel... et al (2020), due to the outbreak of the pandemic, there were bans on large gathering, non essential business, closure of schools and universities, international and domestic mobility restrictions, physical isolation and total lockdowns of regions and countries.by the spread

This study will focus on COVID-19 information seeking and utilization among women in Delta State, Nigeria. There have been several studies have focused on women. However, none has been conducted on COVID-19 information seeking and utilization among women in Delta State, Nigeria. This study was intended to fill this research gap.

\section{STATEMENT OF THE PROBLEM}

Access to relevant information is important in times of outbreak of disease, especially in the current COVID-19 pandemic. People need to have access to information on the nature of the disease, how to stay free from infection, treatment etc. However, the lockdown imposed globally to stem the spread of the virus may affect access to and use of information especially among women. The health of most families in Nigeria is tied to the health and general wellbeing of the women. A Nigerian woman is expected to know about basic health care, and be able to provide some first aid when the need arises, before the sick family memberseeks further assistance (Nwagwu \& Ajama, 2011). The women therefore play very vital role in ensuring that the family is healthy. This role requires women to seekand use health related information. The question is: do the women in Delta State seek and use COVID-19 during the pandemic. This study was intended to address this issue.

\section{OBJECTIVES OF THE STUDY}

The study was intended to explore COVID-19 information seeking and utilization among women in Warri Metropolis, Delta State, Nigeria. The specific objectives were to 
1. identify the COVID-19 information needs of the women;

2. find out the sources of COVID-19 information used by the women;

3. find the criteria/factors used to evaluate the COVID-19 information accessed/used by the women;

4. identify the purposes for which COVID-19 information is used by the women; and,

5. find out what constitutes barriers to COVID-19 information access to the women.

\section{LITERATURE REVIEW}

Research has shown that quarantine measures of infected individuals and their family members combined with surveillance and standard testing procedures are effective as control measures in the early stage of the pandemic (Roo, Cook, Park, Sun, Sun, Lim, Tam \& Dickens, 2020). Iyanda (2020) asserted that in acrisis like the COVID-19 outbreak, people are more curious and eager to know specific information about the disease and that such information include possible strategies and tactics for containment, treatment and vaccines or drugs. Ebhraim, Saif, Buheji, Albasri, Al-Husaini and Jahrami (2020) examined COVID-19 information seeking behavior and anxiety symptoms among parents in Bahrain. Their finding revealed that about $18 \%$ of responding parents had moderate to severe anxiety symptoms. Their finding further revealed that participants utmost priority was to know about how to apply a proper self quarantine with mean score of 4.49 and SD 0.8 . Women would need information on COVID-19 in order to keep their family safe and stay healthy. According to Hafeez, Ahmad, Siddqui, Ahmed and Mishra (2020), common symptoms of COVID-19 include fever, cough, sneezing, shortness of breath and that complication may include pneumonia, throat pain and acute respiratory distress syndrome. They further state that the virus is typically rapidly spread from one person to another via respiratory droplets produced during coughing and sneezing. Older age people and younger adults with serious illness, such as diabetes, heart disease, and lung disease, have a greater risk of becoming severely ill if they get infected with the coronavirus (Hafeez, Ahmad, Siddqui, Ahmed \& Mishra, 2020).

In the same vein, Shereen and Khan (2020) asserted that the virus that causes coronavirus disease 19 (COVID-19) is a highly transmittable and pathogenic viral infection and mainly transmitted through contact with respiratory droplets rather than through the air. Koma and Neuman (2020) noted that Centers for Disease Control and Prevention has issued specific guidance for people who fall into different categories. Preventive measures include washing your hands with soap, covering the mouth when coughing, maintaining 1-meter distance from other people and monitoring and self-isolation for fourteen days for people who suspect they are infected (Center for Disease Control and Prevention, Coronavirus Disease, 2019).

According to Tumpey, Daigle and Nowak (2020), people constantly receive information from many sources ranging from print media, television and social media on mobile services. Similarly, Mitchell, Gottfried, Barthur and Shearer (2016) stated that the Pem Research Center reported that 4 in 10 USA residents received their news from online sources and that 6 in 10 received their news through social media channels. Iyanda (2020) opined that the National Bureau of Statistics noted that a total of 126,078,999 subscribers have been active on the internet as against 123,163,027 in Q3 2019 and 112,065,740 in Q4 2018 and that with these data, analysts believe that the subscribers must have searched specific information about the virus from February $27^{\text {th }}$ through April, 2020. Similarly, Bedford (2020) observed that in the United Kingdom, the government has created a page on COVID-19 which complied all the government publications on the topic as well as a page of information for the public. He further stated that whether one agrees with the policies or not, government sources also tend to be the first with up-to-date statistics. However, Lima, Lopes and Brito (2020) asserted that these days, people are overwhelmed by the information they receive on their smart phones, through channels such as Facebook, Twitter, whatsapp, YouTube and Instagram. This implies that amajority of information on COVID-19 are disseminated through social media. In addition, Lima, Lopes and 
Brito (2020) stated that governments and healthcare authorities should use social media to spread updates, news and scientific discoveries about COVID-19.

Lima, Lopes and Brito (2020) asserted that the majority of the information on COVID-19 are circulated through social media, but the biggest problem is in determining which news to trust. However, Ebhraim, Saif, Buheji,Albasri, Al-Husaini \& Jahrami (2020) study of COVID-19 information seeking behavior and anxiety symptoms among parents in Bahrain revealed that the most reliable source for COVID-19 information is social media account of official health organization followed by health care professionals while the least was in print newspapers health care professionals. Lima, Lopes and Brito (2020) asserted that information from reliable sources such as government health care authorities and specialists should be trusted. According to Chan, Nickson, Rudolph, Lee, Joynit (2020), delivering fast and reliable information is crucial to decrease the transmission of highly contagious infections not only for health care workers but also for the general population. It could be deduced that reliable sources of COVID-19 information is a necessity to prevent the spread. However, Merchant and Lurie (2020) asserted that information on COVID-19 to be spread should include who should be tested, when they should be tested and where they would go to get medical care; that Facebook can redirect users to World Health Organisation (WHO) websites where trustworthy information can be obtained. Walad (2020) asserted that reliable information and safety information is harder to reach for people without access to computers and other gadgets.

Women need access to reliable information and quality care on COVID-19. Women use COVID-19 information to prevent the spread to family members. Information on the pandemic outbreak must be accessed and used to protect women in antenatal, neonatal and maternal health units (United Nation Population Fund, 2020). According to the COVID-19 Occupational Safety and Health Administration, United State Department of Labor (2020), for safe work practice, workers should be adised not have close contact with an infected person by using additional engineering and administrative control. According to Center for Disease Control and Prevention (2020), disinfectant should be applied daily on surfaces such as desks, phones, keyboards, toilets, faucets, tables, doorknobs, light switches, countertops, handles, and sinks.

Ebhraim, Saif, Buheji, Albasri, Al-Husani and Jahrami (2020) study of COVID-19 information seeking behaviors and anxiety symptoms among parents in Bahrain reveal that the most restricting obstacles for seeking COVID-19 information were the spread of rumors and the massive information about the disease. Lima, Lopes and Brito (2020) asserted that we are living not just in a pandemic, but also in an 'infodemic' where fake news is becoming more common. This implies that a major barrier to COVID-19 information access is dissemination of fake news.

\section{METHODS}

The study examines COVID-19 information seeking and utilization among women in Delta State, Nigeria. Descriptive survey research design was adopted for the study. This research design was adopted because it would enable the researcher to collect primary data on the status of the COVID-19 information seeking and utilization among woment in Delta State, Nigeria and did not involve manipulation of variables. The population focus the study consisted of women in Delta State. However, the reseachrs purposively drew the research subjects from two cities in Delta State, Nigeria - Sapele and Warri. The researchers used purposive sampling technique study because of lockdown/partial restriction of movement that was in force in Nigeria as at the time of administering the questionnaire.

The researchers decided to use women for the study because of the health role they play in their families in Nigeria. As observed by Nwagwu \& Ajama (2011), the health of some families in Nigeria is tied to the health and general wellbeing of the women; that the Nigerian woman is expected to know about basic health care and be able to provide some first aid when the need arises, before the sick family member seeks further assistance. The women were used in order to determine whether they were seeking and using COVID-19 information in order to equip them to help themselves and 
their families to keep safe and healthy during the COVID-19 pandemic. Data were collected through the use of a self-constructed questionnaire entitled "COVID-19 Information Seeking and Utilization among Women Questionnaire (COVID-9ISUWQ)." The questionnaire was made up of two sections. The first section focused on the demographic information of respondents while the second section focused on COVID-19 information seeking and utilization consisting of five items: (i) COVID-19 information needs, (ii) sources of COVID-19 information used by the women, (iii) evaluation of sources of COVID-19 information used, (iv) purposes for which COVID-19 information is used, and (v) barriers to COVID-19 information access by the respondents. A total of 325 copies of the questionnaire were administered face-to-face to women two in Delta State with the support of six trained research assistants. However, 299 (92\%) copies of duly filled questionnaires were retrieved, analysed and used for the study. According to Richardson (2005), a response rate of $60 \%$ or more is desirable and adequate for survey research. Therefore, the response rate of $93 \%$ was considered very adequate for the study. The data collected were analysed using frequencies and percentages.

\section{RESULTS AND DISCUSSION}

Out of the 325 copies the questionnaire administered, 180 copies were distributed to women in Warri, but 166 copies were retrieved while 145 copies were distributed to women in Sapele. 133 usable copies were retrieved. The two cities are located in Delta State, Nigeria.

Table 1 reveals the occupations of the women used in this study. Teachers attracted the highest occupational group with $149(49.83 \%)$ respondents. This is a reflection of the fact that teaching is a profession dominated by women. It has been observed by Women's Agenda (2019) that women continue to be overrepresented significantly in teaching, which is often put down to gender differences in occupational preferences (Basten, 1997; Women's Agenda, 2019). This is followed by traders $16(5.35 \%)$. The table clearly reveals that the women belong to various occupations.

Table 2 shows the demographic information of the women used in the study. The table reveals that a majority of them - $222(74.24 \%)$-were married followed by 46 (15.38\%) who were single while $31(10.36 \%)$ were widows.

Table 3 shows the age range of respondents. It reveals that the age range of 45-49 (19.39\%) attracted the highest responses followed by 50-54 (19.06\%), while 50-54 years had the lowest responses $-57(19.06 \%)$. This implies that the majority of the respondents were $45-49$ years; that is, a majority of them were in their mid 40s.

Table 4 reveals the areas the respondents need COVID-19 information. COVID-19 preventive measures attracted the highest responses of 150 (50.16\%). The possible reason for this could be that they would not like to be infected by the coronavirus. As earlier hinted, the health of some families in Nigeria is tied to the health and general wellbeing of the women. The Nigerian woman is expected to know about basic health care and be able to provide some first aid when the need arises, before the sick family member seeks further assistance (Nwagwu \& Ajama, 2011). Therefore, if the woman in a family is infected with the virus, she would not be able to play the role of ensuring that the members of the family are safe and healthy during the pandemic. She would therefore like to know how she and members of the family are prevented from infection by the virus. The populace has been generally advised to adopt preventative measures in order to reduce their risk of coronavirus infection (World Heaith Organisation, 2020c).

Table 5 focuses on the sources of information the respondents access/use to obtain COVID-19 information. The Internet is the source of COVID-19 information used by the highest number of respondents - 193 (64.54\%), followed by television - 174 (58.19\%) and social media -149 (49.83\%) possibly because of easy accessibility of these sources. In 24-hour news and digital media environment of today, people receive information constantly from many sources, which range from print media to television to alerts and social media on mobile devices (Tumpey, Daigle \& Nowak, 2020). The various 
International Journal of Library and Information Services

Volume 10 • Issue 2 • July-December 2021

\section{Table 1. Occupation of the respondents}

\begin{tabular}{|c|c|c|}
\hline Occupation of respondents & Number & Percentage \\
\hline $\begin{array}{l}\text { Teacher } \\
\text { Trader }\end{array}$ & $\begin{array}{l}149 \\
16\end{array}$ & $\begin{array}{l}49.83 \\
5.35\end{array}$ \\
\hline Nurse & 5 & 1.67 \\
\hline Fashion designer & 5 & 1.67 \\
\hline Secretary & 3 & 1.00 \\
\hline Engineer & 2 & 0.66 \\
\hline Cosmetologist & 9 & 3.01 \\
\hline Cake designer & 3 & 1.00 \\
\hline Baker & 1 & 0.33 \\
\hline Physician & 3 & 1.00 \\
\hline Security personnel & 5 & 1.67 \\
\hline Hair stylist & 6 & 2.00 \\
\hline Caterer & 3 & 1.00 \\
\hline Construction expert & 2 & 0.66 \\
\hline Pharmacists & 5 & 1.67 \\
\hline Hotelier & 4 & 1.33 \\
\hline Contractor & 2 & 0.66 \\
\hline Banker & 4 & 1.33 \\
\hline Maids. & 4 & 1.33 \\
\hline Make-up artist & 4 & 1.33 \\
\hline Applicant. & 2 & 0.66 \\
\hline Farmer & 2 & 0.66 \\
\hline Food vendor/Hawker & 3 & 1.00 \\
\hline Cashier & 5 & 1.67 \\
\hline Waitress & 2 & 0.66 \\
\hline Receptionist & 4 & 1.33 \\
\hline Accountant & 5 & 1.67 \\
\hline Cook. & 3 & 1.00 \\
\hline Office clerk & 3 & 1.00 \\
\hline Manager & 1 & 0.33 \\
\hline Administrator assistant & 8 & 2.67 \\
\hline Child care worker & 3 & 1.00 \\
\hline Retiree & 3 & 1.00 \\
\hline School administrator & 1 & 0.33 \\
\hline Doctor & 3 & 1.00 \\
\hline Wedding planner & 1 & 0.33 \\
\hline Medical trainee & 1 & 0.33 \\
\hline Legal practitioner & 1 & 0.33 \\
\hline Student & 4 & 1.33 \\
\hline Church worker & 1 & 0.33 \\
\hline Civil servant. & 3 & 1.00 \\
\hline Administrative officer & 1 & 0.33 \\
\hline Librarian & 2 & 0.66 \\
\hline Assistant registrar & 1 & 0.33 \\
\hline Total & 299 & 100 \\
\hline
\end{tabular}


Table 2. Marital status

\begin{tabular}{|l|l|l|}
\hline Status of respondents & Number & Percentage \\
\hline Single & 46 & 15.38 \\
\hline Married & 222 & 74.24 \\
\hline Widows & 31 & 10.36 \\
\hline Total & 299 & 100 \\
\hline
\end{tabular}

\section{Table 3. Age of the respondents}

\begin{tabular}{|l|l|l|}
\hline Age range & Number & Percentage \\
\hline Below 20 years & 13 & 4.34 \\
\hline $20-24$ years & 18 & 6.02 \\
\hline $25-29$ years & 31 & 10.36 \\
\hline $30-34$ years & 41 & 13.71 \\
\hline $35-39$ years & 21 & 7.02 \\
\hline $40-44$ years & 25 & 8.36 \\
\hline $45-49$ years & 58 & 19.39 \\
\hline $50-54$ years & 57 & 19.06 \\
\hline 55 years and above & 35 & 11.70 \\
\hline Total & 299 & 100 \\
\hline
\end{tabular}

Table 4. COVID-19 Information needs of the respondents

\begin{tabular}{|c|c|c|}
\hline COVID-19 information needs & Frequency & Percentage \\
\hline COVID-19 preventive measures & 150 & 50.16 \\
\hline Information to COVID-19 symptoms & 126 & 42.14 \\
\hline How COVID-19 is transmitted & 123 & 41.13 \\
\hline COVID-19 test procedures & 48 & 16.05 \\
\hline Causes of COVID-19 virus & 118 & 39.46 \\
\hline COVID-19 cure/treatment & 114 & 38.12 \\
\hline Age group most vulnerable to COVID-19 attacks/infection & 115 & 38.46 \\
\hline $\begin{array}{l}\text { COVID-19 patients' isolation } \\
\text { Procedures }\end{array}$ & 25 & 8.36 \\
\hline $\begin{array}{l}\text { Drug/vaccines for COVID-19 } \\
\text { Treatment }\end{array}$ & 113 & 37.79 \\
\hline Movement restriction/curfew & 34 & 11.37 \\
\hline Palliatives & 27 & 9.03 \\
\hline $\begin{array}{l}\text { Government COVID-19 } \\
\text { policies /measures/pronouncements }\end{array}$ & 22 & 7.35 \\
\hline $\begin{array}{l}\text { COVID alternative/herbal/traditional } \\
\text { Treatment }\end{array}$ & 42 & 14.04 \\
\hline
\end{tabular}


Table 5. Sources of COVID-19 information used/consulted

\begin{tabular}{|l|l|l|}
\hline COVID-19 Information sources used & Number & Percentage \\
\hline Internet & 193 & 64.54 \\
\hline Television & 174 & 58.19 \\
\hline Social media (e.g WhatSapp, Facebook etc.) & 149 & 49.83 \\
\hline $\begin{array}{l}\text { Nigeria Centre for Diseases Control } \\
\text { (NCDC) website }\end{array}$ & 128 & 42.80 \\
\hline Government health workers & 82 & 27.42 \\
\hline Friends/family members/neighbours & 72 & 24.08 \\
\hline Radio & 62 & 20.73 \\
\hline Daily newspaper & 52 & 17.39 \\
\hline Associations/co-operativesociety/group meetings & 36 & 12.04 \\
\hline Church & 36 & 12.04 \\
\hline Local town criers & 28 & 9.36 \\
\hline
\end{tabular}

sources that the women consult (as shown in Table 5) would enable them to meet the COVID-19 information needs indicated in Table 4.

Table 6 reveals the criteria/factors the respondents consider when evaluating the COVID-19 use. Evaluating information sources is very important to the user as not all information is reliable or true, nor will all information be suitable for a particular needs. Print and electronic sources vary widely in their authority, accuracy, objectivity, currency, and coverage. Thus users must be able to critically evaluate the appropriateness of all types of information sources before relying on the information (Elmer E. Rasmuson Library, 2020). Table 5 shows that the women in this study consult/used various information, some of which may not be reliable, true, relevant, current etc. It is only natural for them to evaluate the sources (as shown in Table 6) before using them to satisfy their COVID-19 information needs.The table shows that the highest majority of them $192(64.21 \%)$ consider the authority of the source of the information on coronavirus they access possibly to ensure that information is not fake.

Table 7 shows that the highest majority of women (63.21\%) access COVID-19 information to enable them identify symptons of the disease followed by protection against COVID-19 infection (62.54\%) The reasons for the respondents' use of COVID-19 information as could be deduced from

Table 6. Evaluation of sources of COVID-19 Information

\begin{tabular}{|l|l|l|}
\hline Factors & Number & Percentage \\
\hline $\begin{array}{l}\text { Authority of the source(whether from } \\
\text { Government, NCDC, etc) }\end{array}$ & 192 & 64.21 \\
\hline $\begin{array}{l}\text { Accuracy of the source of } \\
\text { Information }\end{array}$ & 189 & 63.21 \\
\hline Usefulness of the information & 173 & 57.85 \\
\hline Reliability of the information source & 155 & 51.83 \\
\hline Whether the information is current & 141 & 47.15 \\
\hline Scope/coverage of the information source & 89 & 29.76 \\
\hline Whether the information is a fact/true & 87 & 29.09 \\
\hline Whether the information can be verified & 85 & 28.42 \\
\hline
\end{tabular}


Table 7. What COVID-19 information is used for

\begin{tabular}{|l|l|l|}
\hline COVID-19 information use & Number & Percentage \\
\hline COVID-19 symptoms identification & 189 & 63.21 \\
\hline For protection against COVID-19 infection & 187 & 62.54 \\
\hline For COVID-19 treatment & 180 & 60.20 \\
\hline For drug dosage for COVID-19 patient treatment & 178 & 59.53 \\
\hline For COVID-19 patients' isolation/quarantine procedures and practices & 152 & 50.83 \\
\hline $\begin{array}{l}\text { Obeying government's regulations during COVID-19 pandemic (e.g movement restriction, } \\
\text { social distancing) }\end{array}$ & 76 & 25.41 \\
\hline
\end{tabular}

the table, have to do with staying healthy and safe from the coronavirus pandemic. It has been revealed in Table 4 that information needs on COVID-19 prevention ranked highest with 50.16\% responses. Preventing COVID-19 would enable the women to stay healthy and safe.

Table 8 reveals that the majority of the respondents experience problem of large amount of COVID-19 unreliable information on social media and other sources in their access and use of COVID-19 information. It has been observed that in our 24-hour news and digital media environment of today, people receive information constantly from many sources, which range from print media to television to alerts and social media on mobile devices (Tumpey, Daigle \& Nowak, 2020). At present, so much information is available and continuously being generated on COVID-19 that people find it difficult to ascertain the reliability of some information. It has been reported that since the beginning of the COVID-19 pandemic, there have been parallel outbreaks of disinformation and misinformation about the virus, which range from fake coronavirus cures, false claims and harmful health advice to wild conspiracy theories; that disinformation can cause further spread of the coronavirus disease, impede effective public health responses, create confusion, fear as well as distrust (Unesco, 2020). It was due to the large amount of unreliable COVID-19 information that necessited the women to evaluate the information on the pandemic in Table 6.

\section{CONCLUSION, RECOMMENDATIONS AND IMPLICATIONS}

The COVID-19 pandemic has generated lots of concerns which require access to and use of relevant information to enable women and their families keep safe and healthy.The women in Delta State observed in this study need Covid 19 information on preventive measures of the pandemic, its causes,

Table 8. Barriers to COVID-19 Information access and use by the respondents

\begin{tabular}{|l|l|l|}
\hline Barriers to COVID-19 information seeking and access & Number & Percentage \\
\hline $\begin{array}{l}\text { Large amount of COVID-19 unreliable information on social media and other } \\
\text { sources }\end{array}$ & 187 & 62.54 \\
\hline Lack of funds to subscribe to data & 177 & 59.19 \\
\hline Poor power supply & 175 & 58.52 \\
\hline Poor internet speed & 159 & 53.17 \\
\hline Too many sources of COVID-19 information & 152 & 50.83 \\
\hline Poor telecommunication networks & 98 & 32.77 \\
\hline Unable to read/illiterate & 70 & 23.41 \\
\hline False information & 57 & 19.06 \\
\hline
\end{tabular}


symptons, age groups vulnerable to it, how it is transmitted and how it can be cured. They consult various of information on COVID-19 but are very concerned about the reliability of sources they consult and use on the pandemic.

Based on the findings of the study, the following are recommended:

1. Effort should be made by government to get mobile network operators to reduce tarrif to enable women and others to easily access COVID-19 information.

2. Government should enforce laws on how to stop fake news on COVID-19 by bringing the perpetrators to book.

This study has focused on COVID-19 infomation needs and utilization among women in Delta State, Nigeria. Other categories of Nigerians like men, youth and teenagers were not investigated. A study that focused on all these categories of people would have been more robust with findings more representative and generalizable. A large scale scale study that explore various strata of the country is therefore recommended.

It would be interesting to conduct a survey of gender difference on COVID-19 information seeking and utilization in Nigeria.

The results of this current study would be of great impact and significance. It has generated primary dated which could assist governments and health institutions/organisations, media and other stake holders to plan and disseminate need information to women during the current and future pandemic(s). 


\section{REFERENCES}

Basten, C. (1997). A feminised profession: Women in the teaching profession. Educational Studies, 23(1), 55-62. doi: $10.1080 / 0305569970230104$

Bedford, D. (2020). Covid 19 seeking Reliable information in difficult times. Retrieved from https://www.infolit .org.uk/covid 19/

Center for disease control and prevention, coronavirus disease 'COVID-19'. (2019). Retrieved from: https:// www.cdc.gov/coronavirus/2019-ncov/symptomstesting/symptom s.html

Chan, A. K., Nickson, C. P., Rudolph, J. W., Lee, A., \& Joynit, G. M. (2020). Social media for rapid knowledge dissemination: early experience from Covid 19 pandemic. Retrieved from https://onlinelibrary.wiley.com./doi/ abs/10.1111/anae

Covid 19 Occupational Safety and Health Adminstration United State Department of Labour. (2020) Guidance on Preparing Workplaces for COVID-19 - OSHA. Retreived from https://www.osha.gov/Publications/OSHA3990.pdf

Ebhraim, A. H., Saif, Z. O., Buheji, M., Albasri, N., Al-Husaini, F. A., \& Jahrami, H. (2020). COVID-19 Information-seeking behavior and anxiety symptoms among parents. Retrieved from https://www.researchgate.net/ publication/341741193_COVID-19_Information-Seeking_Behavior_and_Anxiety_Symptoms_among_Parents

Elmer E. Rasmuson Library (2020). Evaluating Information Resources. Retrieved from https://library.uaf.edu/ 1s101-evaluation

Hafeez, A., Ahmad, S., Siddqui, S. A., Ahmad, M., \& Mishra, S. (2020). A review of COVID-19(Coronavirus Disease-2019). Diagnosis, treatments and prevention. EJMO, 4(2), 116-125.

Igwe, K.N. (2012). Introduction to information science. Offa: Department of Library and Information Science, Federal Polytechnic, Offa.

Iyanda, M. (2020). In 33 days: 1.3 million internet users seek information about coronavirus symptoms in Nigeria. Retrieved from https://www.tekedia.com/in-33days-1-3.million

Koma, W., \& Neuman, T. (2020). How many adults are at risk of serious illness if infected with Coronavirus? Data note. Retrieved fromhttp://files.kff.org/attachment/Data- Note-How-Many-AdultsAre-at-Risk-of-SeriousIllness-If-Infected-with-Coronavirus.pdf

Koo, J. R., Cook, A. R., Park, M., Sun, Y., Sun, H., Lim, J. T., Tam, C., \& Dickens, B. L. (2020). Interventions to mitigate early spread of SARS-CoV-2 in Singapore: a modelling Study. The Lancet Infectious Diseases. Retrieved from https://www.thelancet.com/ journals/laning/article/

Lima, D. L., Lopes, M. A. A., \& Brito, A. M. (2020). Social media: friend or foe in the COVID-19 pandemic? Retrieved from https://dor.org/10.6061/clinics/2020/e/1953

Merchant, R. M., \& Lurie, N. (2020). Social media and emergency preparedness in response to novel Coronavirus. JAMA. doi:10.1001/jama.2020. 4469

Merriam-Webster, Incorporated. (2020). COVID-19. Retrieved from https://www.merriam-webster.com/ dictionary/COVID-19

Mitchell, A., Gottfried, J., Barthur, M., \& Shearer, E. (2016). The modern news consumer: news attitudes and practice in the digital era. The Pew Research Center.

Nwagwu, W. E., \& Ajama, M. (2011). Women's health information needs and information sources: A study of a rural oil palm business community in South-Western Nigeria. Annals of Library and Information Studies, $58,270-281$.

Oliver, N., Lepri, B., Sterly, H., \& Renavel, L. (2020). Mobile phone data for informing public health actions across the Covid 19 pandemic life cycle. Science Advances, 6(23), 764. doi:10.1126/sciadv.abc0764 PMID:32548274

Richardson, J. T. E. (2005). Instruments for obtaining student feedback: A review of the literature. Assessment \& Evaluation in Higher Education, 30(4), 387-415. doi:10.1080/02602930500099193 
Shereen, M. A., Khan, S., Kazmi, A., Bashir, N., \& Siddique, R. (2020). COVID-19 infection: Origin, transmission, and characteristics of human coronaviruses. Journal of Advanced Research, 24, 91-98. doi:10.1016/j. jare.2020.03.005 PMID:32257431

Tumpey, A. J., Daigle, D., \& Nowak, G. (2020). Communicating during an outbreak or public health investigation. Retrieved from https:www.cde.gov/eis/field-eps-manual/chapters/communicating-investigation.tml

UNESCO. (2020). 'Fake news' in the time of COVID-19. Retrieved from https://bangkok.unesco.org/content/ press-provides-antidote-fake-news-time-covid-19

United Nation Population Fund. (2020). As COVID-19 continues to spread, pregnant and breastfeeding women advised to take precautions. Retrieved from https://www.unfpa.org/news/covid-19-continues-spread-pregnantand-breastfeedings

Vanguard Media Limited (2020). COVID-19: Delta Assembly calls for more sensitization. Retrieved from callsfor-more-sensitisation/

Walad, E. (2020). Coronavirus pandemic is exposing the gender digital divide. Retrieved from https://insight. wfp.org/coronavirus/pandemic-is-exposing the gender digital/divide

Wang, C., Horby, P. W., Hayden, F. G., \& Goa, G. F. (2020). A novel Coronavirus outbreak of global health concern. Retrieved from https://www.ncbi.nlm.nih.gov/pmc/articles/pmc7135038

Warner, D., \& Procaccino, D. (2004). Toward wellness: Women seeking health information. Journal of the American Society for Information Science and Technology, 55(8), 709-730. doi:10.1002/asi.20016

Women's Agenda. (2019). Is teaching dominated by women because men get better pay elsewhere? Retrieved from https://womensagenda.com.au/latest/is-teaching-dominated-by-women-because-men-get-better-pay-elsewhere/

World Health Organization. (2020a). WHO concerned over COVID-19 impact on women, girls in Africa. Retrieved from https://www.afro.who.int/news/who-concerned-over-covid-

World Health Organization. (2020b). WHO Director-General's opening remarks at the media briefing on COVID-19 - 11. Retrieved from https://www.who.int/director-general/speeches/detail/who-director-general-sopening-remarks-at-the-media-briefing-on-covid-19---11-march-2020

World Health Organization. (2020c). 7 tips to reduce risk of coronavirus (COVID-19). Retrieved from https:// retriv/www.afro.who.int/node/12353 


\section{APPENDIX}

\section{QUESTIONNAIRE}

\section{COVID-19 Information Seeking and Utilization among Women Questionnaire(COVID-19ISUWQ)}

Federal University of Petroleum Resources

Library,

PMB 1221 Effurun,Delta State, Nigeria

$30^{\text {th }}$ June, 2020

Dear respondent,

The researchers are currently conducting a research on COVID-19 information seeking and utilization among women in Delta State.This questionnaire is intended to assist the researchers in gathering relevant and useful information needed strictly for academic purpose only. All information provided by you will be treated confidentially and used mainly for the purpose of this research.

Thanks for your anticipated cooperation.

Yours Faithfully,

Signed:

Dr (Mrs) Gloria O. Oyovwe-Tinuoye and Prof. Esharenana E.Adomi

Researchers

\section{SECTION A: DEMOGRAPHIC CHARACTERISTICS OF THE RESPONDENTS}

INSTRUCTION: Please tick (Ö) the appropriate box as applicable to you and as it suites your opinion.

I. Age: Below 20 years () 20 - 24 years () 25 - 30 years() $3 \mathrm{i}-34$ years() $35-39$ years () $40-44$ () $45-49$ () $50-54$ () 55 years and above ()

II. Occupation: trader () teacher () nurse() fashion designer () Secretary () computer operator () office machine operator except computer () security personel () hair stylist () caterer () construction expert () engineering () cosmetologist () cake designer () baker () physician () pharnercist () hotelier () contractor () banker () maids and house cleaner () make up artist () applicant () farmer () food vendor/haker () cashier () waitress () receptionist () accountant () cook () office clerk () missionary/clergy () manager () administrative assistant () child care worker ()

Others (please specify)

III. Marital status: Single () Married () Widowed ()

\section{SECTION B: COVID 19 INFORMATION NEEDS}

INSTRUCTION: Please tick (Ö) the appropriable box(es)indicating your agreement

1. Please indicate the aspects of COVID-19 you need information?

Others (please specify)

\section{SECTION B: SOURCES OF COVID 19 INFORMATION OF RESPONDENTS}

Instruction: Please tick () the appropriable box(es)for your choice of COVID 19 information source 


\begin{tabular}{|l|l|l|}
\hline S/N & Aspects of COVID-19 information needs & Tick (Ö) \\
\hline 1 & Causes of COVID-19 virus. & \\
\hline 2 & Information on COVID 19 symptoms. & \\
\hline 3 & COVID-19 test procedures. & \\
\hline 4 & How COVID 19 spreads/is transmitted & \\
\hline 5 & COVID-19 preventive measures. & \\
\hline 6 & COVID-19 cure/treatment & \\
\hline 7 & Age group most vulnerable to COVID-19 attack/infection. & \\
\hline 8 & COVID-19 patients' isolation procedures. & \\
\hline 9 & Drug/vacines for COVID-19 treatment. & \\
\hline 10 & Movement restriction/curfew & \\
\hline 11 & Palliative & \\
\hline 12 & Government COVID- policies/measures/pronouncements & \\
\hline 13 & COVID alternative/herbal/traditional treatment & \\
\hline
\end{tabular}

2. What are the sources you use/rely on to obtain information on COVID-19?

Others (please specify)

\section{SECTION B: EVALUATION OF SOURCES OF COVID 19 INFORMATION}

Instruction: Please tick () the appropriable box(es) for your choice of COVID 19 information source evaluation

3. Please indication factors you considered in evaluating/verifying the quality of the sources of COVID-19 information you seek/access and use.

Others (please specify)

\begin{tabular}{|l|l|l|}
\hline S/N & COVID 19 Information Source & Tick (Ö) \\
\hline 1 & Friends/ family members/neighbours & \\
\hline 2 & Government health workers & \\
\hline 3 & Daily newspapers & \\
\hline 4 & Market association/cooperative society/group meetings & \\
\hline 5 & Internet & \\
\hline 6 & Local town carriers & \\
\hline 7 & Social media (egWhatSapp, Facebook etc) & \\
\hline 8 & Nigerian Centre for Diseases Control (NCDC) website. & \\
\hline 9 & Television & \\
\hline 10 & Radio & \\
\hline 11 & Church & \\
\hline & & \\
\hline
\end{tabular}




\begin{tabular}{|l|l|l|}
\hline S/N & Factors & Tick (Ö) \\
\hline 1 & $\begin{array}{l}\text { Authority of the source(whether from government, Nigeria Centre for Disease } \\
\text { Control (NCDC),etc) }\end{array}$ & \\
\hline 2 & Accuracy of the source of information & \\
\hline 3 & Reliability of the information source & \\
\hline 4 & Scope/coverage of the information source & \\
\hline 5 & Usefulness of the information & \\
\hline 6 & Whether the information can be verified & \\
\hline 7 & Whether the information is current & \\
\hline
\end{tabular}

\section{SECTION D: USAGE OF COVID 19 INFORMATION BY THE RESPONDENTS}

INSTRUCTION: Please tick () the box indicating your usage of COVID-19 information

4. For what purpose doyou use COVID 19 information?

Others (specify)

\section{SECTION E: BARRIERS TO COVID 19 INFORMATION ACCESS BY THE RESPONDENTS}

INSTRUCTION: Please tick (Ö) the appropriate box indicating the barriers you encounter while seeking/accessing COVID 19 information.

5. What are the barriers to your COVID 19 information access/use?

Others (please specify)

\begin{tabular}{|l|l|l|}
\hline S/N & COVID 19 Information Use & Tick (Ö) \\
\hline 1 & COVID 19 symptoms identification & \\
\hline 2 & For COVID 19 patients isolation/quarantine procedures and practices. & \\
\hline 3 & For COVID 19 treatment & \\
\hline 4 & For drug dosage for COVID 19 patient treatment. & \\
\hline 5 & For protection against COVID 19 infection & \\
\hline 6 & $\begin{array}{l}\text { Obey government regulation on COVID-19(egcomplying with movement } \\
\text { restriction etc) }\end{array}$ & \\
\hline
\end{tabular}




\begin{tabular}{|l|l|l|}
\hline S/N & Barriers to COVID 19 Information Seeking and Access & Tick (Ö) \\
\hline 1 & Unable to read / illiterate . & \\
\hline 2 & Poor Telecommunication networks in Nigeria & \\
\hline 3 & Poor internet speed & \\
\hline 4 & Lack of funds to subscribe to data. & \\
\hline 5 & $\begin{array}{l}\text { Large amount of COVID 19 ubreliable/incredible information on the } \\
\text { Social media and other sources }\end{array}$ & \\
\hline 6 & Poor power supply & \\
\hline 7 & Too many sources of COVID 19 information. & \\
\hline
\end{tabular}

